\title{
$\begin{array}{llllllllllllllllllllllll}P & R & Z & E & G & L & A & D & Z & A & C & H & O & D & N & I & O & P & O & M & O & R & S & K\end{array}$ ROCZNIK XXXIV (LXIII) ROK 2019 ZESZYT 1
}

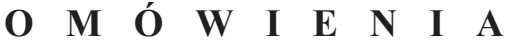

\author{
KRZYSZTOF WASILEWSKI \\ ORCiD: 0000-0002-5378-2822 \\ Wydział Humanistyczny, Politechnika Koszalińska \\ e-mail:krzys.wasilewski@gmail.com
}

\section{SZCZECIŃSKIE CZASOPISMA W PRZESTRZENI SPOLECZNEJ, ReD. D. DĄBrowska, P. Olechowska, I. SOKALSKi, Książnica Pomorska, Szczecin 2019}

Potencjał ludnościowy i kulturowy Szczecina predestynuje to miasto do odgrywania roli regionalnego centrum medialnego Pomorza Zachodniego. Chociaż dotychczasowe analizy medioznawcze zawężają jego pole oddziaływania do dawnego województwa szczecińskiego, nie sposób nie zauważyć, że rola Szczecina zdecydowanie wykracza poza dotychczasowe granice administracyjne, zwłaszcza przy zauważalnym słabnięciu drugiego ośrodka regionalnego, czyli Koszalina1. Mimo to rosnące znaczenie miasta na regionalnym rynku medialnym nie znajduje swojego odzwierciedlenia w liczbie artykułów i publikacji naukowych poświęconych temu

\footnotetext{
${ }^{1}$ Por. M. Jachimowski, Regiony periodycznej komunikacji medialnej, Katowice 2006, s. 294.
}

zagadnieniu. Podobnie zresztą jak media regionalne i lokalne $\mathrm{w}$ innych częściach kraju, także szczecińskie radio, prasa i telewizja pozostają w dużej mierze nieopisane. Powodów tej sytuacji jest kilka. Bez wątpienia do najważniejszych z nich należy widoczny w polskiej nauce nacisk na (często sztuczne) umiędzynarodowienie i uniwersalizację tematów badawczych, co nie sprzyja zainteresowaniu rodzimych naukowców tematyką lokalną. To z kolei przekłada się na poziom finansowania badań. Innymi słowy, problemy, z którymi muszą obecnie mierzyć się historycy zajmujący się dziejami regionalnymi, dotykają także politologów, socjologów czy medioznawców. Niestety szans na pozytywny przełom w tej kwestii na razie nie widać.

Prowadzenie systematycznych badań nad mediami lokalnymi i regionalnymi 
jest zatem trudne do realizacji. Nic więc dziwnego, że najczęściej tym segmentem mediów zajmują się pasjonaci, od których zapału i samozaparcia zależy, czy najważniejsze - z punktu widzenia lokalnej społeczności - media doczekają się nie tylko opisu, ale przede wszystkim wnikliwej naukowej analizy. Trzeba przyznać, że Szczecin ma szczęście do takich osób, stąd i liczba publikacji na ten temat - w porównaniu z resztą kraju - jest całkiem spora. Spośród nich warto wymienić chociażby prace Tadeusza Białeckiego i Krzysztofa Flasińskiego $^{2}$. Do grona badaczy tego zagadnienia zalicza się także dr Paulina Olechowska, zawodowo związana z Zakładem Mediów i Komunikowania w Instytucie Polonistyki, Kulturoznawstwa i Dziennikarstwa Uniwersytetu Szczecińskiego. Jest ona autorką licznych artykułów, a także trzech monografii, w tym pionierskiej pracy poświęconej szczecińskiej prasie szkolnej ${ }^{3}$. To właśnie m.in. z inicjatywy i przy współredakcji Olechowskiej

${ }^{2}$ M.in. T. Białecki, Czasopiśmiennictwo polskie na Pomorzu Zachodnim w latach 1945-1949, „Przegląd Zachodniopomorski" 1968, nr 4; tenże, Prasa szczecińska, w: 25 lat prasy na ziemiach zachodnich i pótnocnych, Kraków 1972; K. Flasiński, Od drukarni do Facebooka. Przemiany prasy codziennej $w$ Szczecinie $w$ latach 1989-2014, Warszawa 2015.

${ }^{3}$ P. Olechowska, Akcesja Polski do Unii Europejskiej na łamach prasy regionalnej Ziem Zachodnich, Szczecin 2012; taż, Prasa szkolna. Teoria, funkcje, tematyka. Analiza na przyktadzie województwa zachodniopomorskiego, Szczecin 2015; taż, „Mosty nad granica”. Polsko-Niemiecka Nagroda Dziennikarska w latach 19972015, Szczecin 2017. powstała publikacja Szczecińskie czasopisma $w$ przestrzeni społecznej, która swoją premierę miała w pierwszym kwartale 2019 roku. Dwójka pozostałych redaktorów tomu również należy do czołowych badaczy szczecińskiej prasy. Profesor Danuta Dąbrowska to postać powszechnie znana i ceniona w świecie szczecińskiej humanistyki, uznana w kraju historyczka literatury, przez wiele lat kierowniczka Zakładu Literatury i Kultury XIX wieku w Instytucie Polonistyki, Kulturoznawstwa i Dziennikarstwa Uniwersytetu Szczecińskiego. Niestety nie dożyła premiery książki, do której wydania walnie się przyczyniła. Trzecim redaktorem omawianej publikacji jest ks. dr Ireneusz Sokalski, autor licznych prac związanych z mediami religijnymi, rzecznik prasowy diecezji szczecińsko-kamieńskiej, do 2018 roku adiunkt we wspomnianym Instytucie Polonistyki, Kulturoznawstwa i Dziennikarstwa.

Redaktorzy książki podzielili jej zawartość na dwie części. Pierwsza - zatytułowana „Zagadnienia ogólne” - zawiera pięć artykułów szeroko podejmujących kwestię szczecińskiej prasy. Rozpoczynający tę część tekst, pióra Danuty Dąbrowskiej, stanowi niejako wprowadzenie w tematykę całego wydawnictwa, gdyż przedstawia stan badań nad ogółem szczecińskiego czasopiśmiennictwa. Autorka trafnie wskazuje w nim na brak usystematyzowanych badań nad lokalną prasą. W konsekwencji wiele tytułów wciąż nie doczekało się szerszego omówienia, zaś w ukazujących się publikacjach ma się często do czynienia $\mathrm{z}$ chaosem terminologicznym. Zdaniem 
Dąbrowskiej rosnące rozdrobnienie prasy lokalnej oraz efemeryczność niektórych tytułów dodatkowo utrudnia pogłębione badania. Nie sposób też nie zgodzić się $\mathrm{z}$ autorką, że niezbędne są prace monograficzne, przynajmniej najważniejszych tytułów, ,zawierające analizę zawartości i profili ideowych (...) ich wpływy społeczne i środowiskowe".

Pozostałe artykuły w pierwszej części książki poświęcone są próbie wyjścia naprzeciw postulatom Dąbrowskiej i wypełniają luki w dziejach prasy szczecińskiej. Ireneusz Sokalski przybliża „osobowości w kręgu szczecińskich dziennikarzy”. $\mathrm{W}$ artykule znajduje potwierdzenie teza, iż rola indywidualności $\mathrm{w}$ kształtowaniu dziennikarstwa, zwłaszcza lokalnego, jest trudna do przecenienia. Krzysztof Flasiński z kolei omawia zasięg, wydawców i tematykę czasopism ukazujących się w Szczecinie po 1989 roku. Minione trzy dekady to lata prawdziwego rozkwitu prasy lokalnej, a zarazem najsłabiej zbadane z powojennych dziejów miasta. Pierwszymi latami „polskiego Szczecina” zajmuje się natomiast Paweł Szulc, który opisuje jednodniówki na Pomorzu Zachodnim z okresu stalinizmu. Pierwszą część kończy tekst Grzegorza Wejmana na temat pism diecezjalnych archidiecezji szczecińsko-kamieńskiej.

Równie interesująco przedstawia się część druga książki zatytułowana „Studia monograficzne”. Można je traktować jako studia przypadków poszczególnych tytułów, stanowiące pionierskie opracowania monograficzne wybranych periodyków. Są to zarazem czasopisma mało znane w powszechnym obiegu, często pisma fachowe, skierowane do wąskiego grona odbiorców. Tym bardziej należy docenić autorów, że „odkryli” te tytuły i postanowili je szczegółowo opisać. W tekście otwierającym drugą część Barbara Popiel przybliża dzieje gazety teatralnej „Gabit”, wydawanej przez Teatr Lalek „Pleciuga” w Szczecinie. Ten segment prasy pozostaje niemal zupełnie niezbadany - także w skali kraju. Wypada tego żałować, gdyż - jak udowadnia to w swoim tekście Popiel - czasopisma teatralne to niezwykle interesujący i wdzięczny temat badawczy. Innym pismem specjalistycznym są ,Roczniki Socjologii Morskiej PAN. Annuals of Marine Sociology", którego historię opisuje Maciej Kowalewski. Ten periodyk naukowy, ukazujący się od ponad 30 lat nakładem Komisji Socjologii Morskiej PAN, stanowi przykład wykorzystania możliwości oferowanych przez cyfrową dystrybucję do poszerzenia grupy odbiorców, również o tych spoza kraju. Do kategorii pism branżowych należy także zaliczyć „Obserwatora Morskiego”, wydawanego od 2008 roku w Szczecinie. Jego redakcję, cele i zawartość przybliża na łamach omawianej książki Małgorzata Kamola-Cieślik. Z kolei współredaktorka tomu, wspomniana już Paulina Olechowska, przygotowała monografię czasopisma „Dialogi. Miesięcznik Pedagogiczny”, które od ponad dwóch dekad ukazuje się nakładem Pomorskiego Centrum Edukacji. Ostatnim w tej części artykułem jest tekst krakowskiego badacza prasy alternatywnej Mateusza Flonta. Na dwudziestu stronach autor przybliża dzieje szczecińskiego 
„Garażu” - punkowego zina, wydawanego w latach 1985-2012. Warto przy tym zauważyć, że w przeciwieństwie do szczecińskiej prasy drugiego obiegu, która została już dosyć dobrze zbadana, lokalne czasopisma trzeciego obiegu wciąż pozostają szerzej nieznane.

Szczecińskie czasopisma $w$ przestrzeni społecznej to książka, która bez wątpienia wnosi wiele nowych informacji do dziejów lokalnej prasy. Szerokie potraktowanie tematu sprawia, że zamieszczone w niej artykuły w mniejszym lub większym zakresie poruszają różnorodne zagadnienia dotyczące szczecińskiego czasopiśmiennictwa doby powojennej. Warto zatem potraktować tę książkę nie tylko jako uzupełnienie już istniejącej literatury przedmiotu, ale także jako wprowadzenie do dalszych badań. Podsumowuje ona bowiem dotychczasowy dorobek, a zarazem wskazuje luki, które należy zapełnić. Redaktorzy tomu trafnie zauważają we „Wstępie”, że media lokalne ,zajmują ważne miejsce wśród aktorów lokalnego życia publicznego i stanowią nie tylko płaszczyznę bieżącej informacji o lokalnej społeczności, ale i kształtują opinię publiczną, kreując tym samym lokalną rzeczywistość". Wypada zatem mieć nadzieję, że omawiana książka zainspiruje kolejnych badaczy do zajęcia się tematem szczecińskich mediów.

$\mathrm{Na}$ zakończenie warto podkreślić, iż wydanie książki było możliwe dzięki dotacji Urzędu Miasta Szczecin. Sam zapał badawczy pasjonatów nie wystarczy, potrzebne są jeszcze odpowiednie środki finansowe. Oby nadal i jednych, i drugich nie brakowało. 